\title{
Effect of Sand Partial Substitution for Glass Powder on the Behaviour of Sand-Cement Mortar
}

\author{
Séraphin Agré Djomo', Conand Honoré Kouakou ${ }^{2 *}$, Koffi Clément Kouadio², \\ Moro Olivier Boffoue ${ }^{2}$, Edjikémé Emeruwa²
}

\author{
${ }^{1}$ Departement Sciences de la Terre, UFR Environnement, Universite Jean Lorougnon Guede, Daloa, Côte d'Ivoire \\ ${ }^{2}$ Laboratoire de Géomatériaux et Technologie du Bâtiment (LGTB), UFR des Sciences de la Terre et des Ressources Minières, \\ Université Felix Houphouet Boigny de Cocody, Abidjan, Côte d’Ivoire \\ Email: *honore_kouakou2@yahoo.fr
}

How to cite this paper: Djomo, S.A., Kouakou, C.H., Kouadio, K.C., Boffoue, M.O. and Emeruwa, E. (2019) Effect of Sand Partial Substitution for Glass Powder on the Behaviour of Sand-Cement Mortar. Materials Sciences and Applications, 10, 756-767.

https://doi.org/10.4236/msa.2019.1012055

Received: July 24, 2019

Accepted: December 17, 2019

Published: December 20, 2019

Copyright $\odot 2019$ by author(s) and Scientific Research Publishing Inc. This work is licensed under the Creative Commons Attribution International License (CC BY 4.0).

http://creativecommons.org/licenses/by/4.0/

(C) (i) Open Access

\begin{abstract}
Partial substitution of aggregates for pieces of glass in concrete contributes to reducing the use this resource and preserving the environment for future generations. However, concretes or mortars mixed with crushed glass can deteriorate within a few years, because of the alkali-silica reaction related to the size of glass pieces. Some investigations were carried out in order to find out how to bring down this phenomenon. Different percentages of glass powder were mixed with mortar made from sand, cement and crushed glass pieces of which diameter is between 1 and $5 \mathrm{~mm}$. Products obtained were submitted to flexural testing, compressive strength testing and resistance to acid attack and Scanning Electron microscopy (SEM) observations were made after a period running from 28 to 180 days of drying. The results show an increase in the mechanical properties of products with glass powder and an improvement in the durability of mortar in acidic environment. Such improvements are related to the enhanced adhesion created between crushed glass pieces and cementitious matrix containing glass powder as a result of pozzolanic reaction.
\end{abstract}

\section{Keywords}

Pozzolanic Reaction, Crushed Glass, Glass Powder, Alkali-Silica Reaction

\section{Introduction}

Every year, millions of tons of glass bottles are produced worldwide. Industries located in the European Union, China and the United States produce about 33 
Mt (million tons), $32 \mathrm{Mt}$ and $20 \mathrm{Mt}$ respectively [1]. These bottles are used to store products and are distributed worldwide where they turned out to be non-biodegradable waste. In developed countries, a greater or lesser proportion (depending on the country) is recycled, while a large number is disposed of in landfills. In France, for example, the glass recycling rate is about $75 \%$ [2]. It can reach $77.9 \%$, or 3 out of 4 bottles, $100 \%$ of which come from the glass collection system [3]. In contrast, in Quebec in 2018, 28\% of glass is sent for recycling [4]. Unlike in developing countries, where there is no bottle sealing and recycling system, bottles are found in streams, lagoons and swamps. In Côte d'Ivoire, for example, millions of these bottles are thrown into the wild every year, where they become larval sites for the proliferation of disease-causing agents associated with stagnant water such as malaria. According to [5] 435,000 people died from malaria in 2017. The African region alone accounts for $93 \%$ of the total number of people who died from malaria. Glass bottles are a real environmental issue. In order to reduce this high mortality rate and especially the environmental impact caused by glass bottles, attempts must be made to recover them in the construction sector. It can be an excellent way to develop an economic and environmentally friendly infrastructure.

In the literature, several publications have been produced by authors on this subject. Thus, some researchers have used glass bottles as aggregates (diameter > $1 \mathrm{~mm}$ ) in concrete or mortar and even in tile making [6]. However, possible alkali-silica reactions in these materials may prevent their use by the general public. Indeed, alkali-silica reactions (ASR) have many consequences, the most alarming of which are irreversible swellings that result in cracks in structures, a decrease in the mechanical properties of the affected concrete [7] [8] [9]. These reactions occur when the alkaline ions contained in a porous solution react with the reactive silica of the aggregates. However, according to [10] [11] there are many alkaline sources. Nevertheless, cement is the main alkaline source $\left(\mathrm{Na}^{+}\right.$ and $\mathrm{K}^{+}$) that are released into the interstitial solution during hydration (Figure 1) [12]. As a result, though the reaction cannot be stopped, it must be slowed down or the reaction of free silica inhibited. Conversely, other researchers have used glass powder (diameter $<140 \mu \mathrm{m}$ ) as a mineral addition in cement or concrete [13] [14] [15]. They affirm the existence of a pozzolanic reaction between glass powder and cement that allows the improvement of concretes and mortars performance. However, using only glass powder will require a high level of grinding that requires a lot of energy. In addition, it quickly wears out the mill parts due to glass abrasiveness.

This project therefore aims to explore another approach to glass bottle use in construction. By using crushed glass with a particle size of less than $2 \mathrm{~mm}$, it is possible to save up the grinding time and take advantage of the pozzolanic reaction to slow down the alkali-silica reaction. The purpose of this project is to highlight the effects of glass powder on the alkaline silica reaction in an alkaline medium. For this purpose, crushed glass bottles will partially replace the sand in the mortars. 


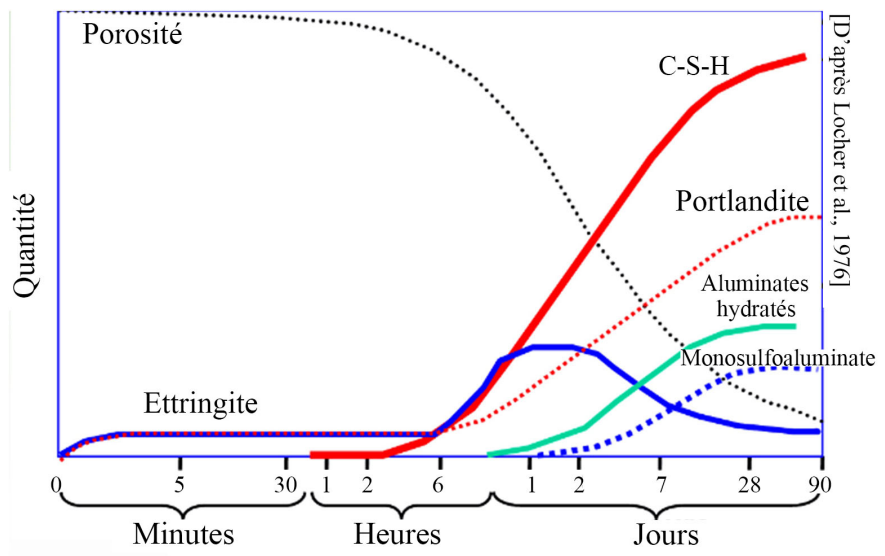

Figure 1. Variation of mineral quantity in the cement mortar for different times (C-S-H: Calcium Silicate Hydrate) [16].

Sand is a natural raw material resulting from the alteration of rocks. According to "Wentworth Modifiée" and "Gardistat", sand consists of particles between $0.063 \mathrm{~mm}$ and $2 \mathrm{~mm}$ in size [17]. In Côte d'Ivoire, the sand used for construction is extracted from rivers and lagoons. This activity modifies the aquatic ecosystem and affects the development of benthic and digging aquatic animals. In this way, replacing sand with crushed glass bottles will increase the proportion of glass recycling in building materials and protect this aquatic environment. Therefore, this work specifically aims to determine the optimum rate of sand substitution by glass and reduce the use of lagoon sand.

\section{Material and Experimental Methodology}

\subsection{Hardware Properties}

\subsubsection{Cement}

The cement used in this study is white cement of CEM I type and $52.5 \mathrm{MPa}$ class. Its specific surface area determined by Blaine method is $3820 \mathrm{~cm}^{2} / \mathrm{g}$. Its chemical composition is given in Table 1 . The content in alkaline $\left(\mathrm{KO}+\mathrm{Na}_{2} \mathrm{O}\right)$ $0.3 \%$ and in $\mathrm{SO}_{3} 2.47 \%$ are within the limits set by [18] which are respectively $0.66 \%-0.90 \%$ and less than $3 \%$.

\subsubsection{Aggregates}

The aggregates used were classified in two groups according to their size: fine aggregates and coarse aggregates.

- Fine aggregates (diameter $<2 \mathrm{~mm}$ ), mainly sand and crushed glass powder.

The sand was extracted from the lagoon. Its particle size distributions shown in Figure 2 were determined by using sieve column. Its fineness modulus and sand equivalent are respectively $2.15 \%$ and $97.5 \%$.

Figure 3 shows X-ray diffractogram of sand obtained by using X-ray diffractometer with $\mathrm{Co}-\mathrm{K} \alpha$ radiation. The peaks were identified with a software called "diffract plus Evra version 12" which indicate that sand was constituted essentially of quartz grains $\left(\mathrm{SiO}_{2}\right)$ (Figure 3 ). The glass powder was obtained by grind- 
ing used bottle. The two types of bottle used were brown bottles (PBB) and green bottles (PBV). These glass powders particle size distributions and chemical compositions were determined respectively by using sedimentology and X-ray fluorescence analysis.

Figure 4 and Table 2 show the particle size and chemical composition of these two types of glass powder. Their proportion in $\mathrm{SiO}_{2}+\mathrm{Al}_{2} \mathrm{O}_{3}+\mathrm{Fe}_{2} \mathrm{O}_{3}$ is $65.78 \%$ and $69.84 \%$ respectively for green and brown colored bottles. $\mathrm{The}_{3} \mathrm{SO}_{3}$ content is less than $0.1 \%$. Brown bottles can be considered as pozzolans, since the sum $\mathrm{SiO}_{2}+\mathrm{Al}_{2} \mathrm{O}_{3}+\mathrm{Fe}_{2} \mathrm{O}_{3}$ is approximately $70 \%$ and the $\mathrm{SO}_{3}$ content is lower than the maximum limit value of $4 \%$. In contrast, brown bottles do not meet all the ASTM C618 requirements so, they are not pozzolans [19]. According to [20], the chemical compositions of clear glass powder and colored glass powder are very similar. So, these materials could be considered as pozzolanic materials. The fineness modules and the Blaine-specific surfaces of both glass powder are respectively 1.44; $1121 \mathrm{~cm}^{2} / \mathrm{g}$ and $1.85 ; 906 \mathrm{~cm}^{2} / \mathrm{g}$ for both brown and green bottles.

- Coarse aggregates $(2 \mathrm{~mm}<$ diameter $<5 \mathrm{~mm})$ are broken shards of crushed brown bottles. They were chosen because their chemical composition does not make them pozzolans.

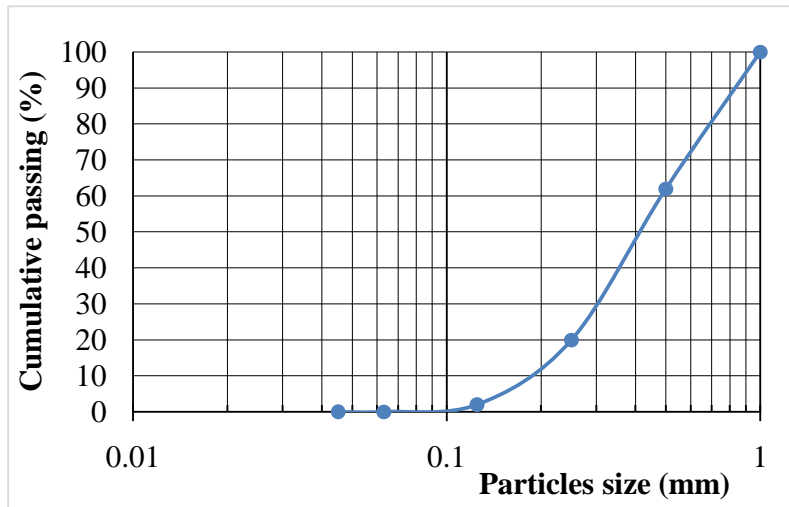

Figure 2. Sand particles size distribution.

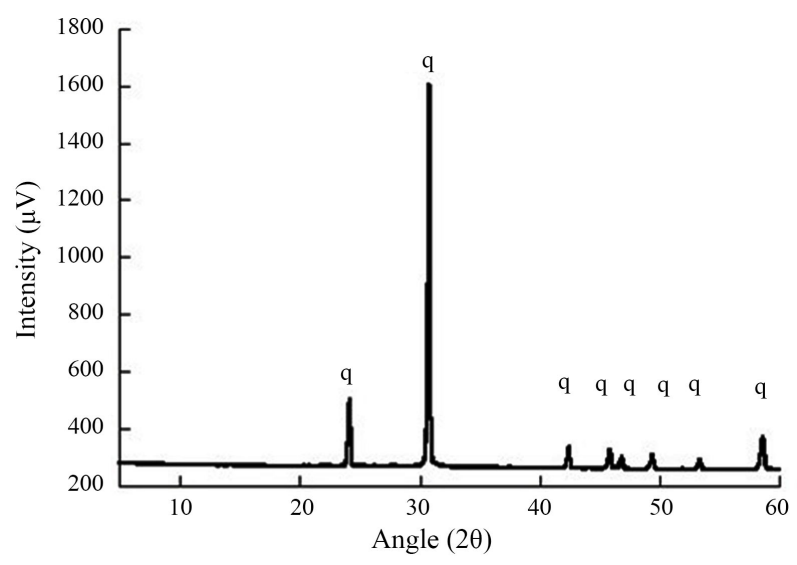

Figure 3. X-ray diffractogram of sand (q) quartz. 


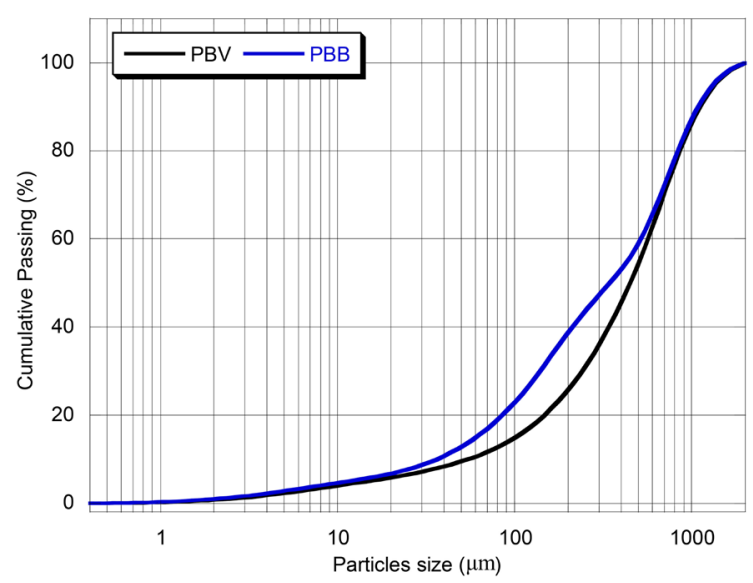

Figure 4. Particles size distribution of glass powders.

Table 1. Chemical composition of cement.

\begin{tabular}{ccccccccccccc}
\hline Oxides & $\mathrm{SiO}_{2}$ & $\mathrm{AL}_{2} \mathrm{O}_{3}$ & $\mathrm{Fe}_{2} \mathrm{O}_{3}$ & $\mathrm{CaO}$ & $\mathrm{MgO}$ & $\mathrm{K}_{2} \mathrm{O}$ & $\mathrm{Na}_{2} \mathrm{O}$ & $\mathrm{MnO}$ & $\mathrm{SO}_{3}$ & $\mathrm{TiO}_{2}$ & $\mathrm{SrO}$ & $\mathrm{Cr}_{2} \mathrm{O}_{3}$ \\
\hline $\begin{array}{c}\text { Content } \\
(\%)\end{array}$ & 18.40 & 3.70 & 3.35 & 67.36 & 0.07 & 0.29 & 0.01 & 0.07 & 2.47 & 0.10 & 0.05 & 1.73 \\
\hline
\end{tabular}

Table 2. Chemical composition of bottles.

\begin{tabular}{ccccccccccccccc}
\hline Oxides & $\mathrm{SiO}_{2}$ & $\mathrm{AL}_{2} \mathrm{O}_{3}$ & $\mathrm{Fe}_{2} \mathrm{O}_{3}$ & $\mathrm{CaO}$ & $\mathrm{MgO}$ & $\mathrm{K}_{2} \mathrm{O}$ & $\mathrm{Na}_{2} \mathrm{O}$ & $\mathrm{BaO}$ & $\mathrm{SO}_{3}$ & $\mathrm{TiO}_{2}$ & $\mathrm{SrO}$ & $\mathrm{Cr}_{2} \mathrm{O}_{3}$ & $\mathrm{P}_{2} \mathrm{O}_{5}$ \\
\hline $\mathrm{PBB}(\%)$ & 62.80 & 1.60 & 1.38 & 10.10 & 1.15 & 0.57 & 17.50 & $<0.01$ & $<0.10$ & $<0.05$ & 0.02 & $<0.62$ & $<0.01$ \\
$\mathrm{PBV}(\%)$ & 67.20 & 1.58 & 0.46 & 10.10 & 1.06 & 0.53 & 17.70 & $<0.08$ & $<0.09$ & 0.09 & 0.04 & 0.22 & $<0.02$ \\
\hline
\end{tabular}

\subsection{Sample Production}

Mortars are made with sand (25\%), cement (21\%) and coarse aggregates (54\%). They were prepared according to [21]. The amount of mixing water was kept regular for all samples: $\mathrm{W} / \mathrm{C}=0.6$. Some glass powder is added in substitution for sand. The percentage of substitution varies from $10 \%$ to $65 \%$ for each type of bottle. Samples of mortars $40 \times 40 \times 160 \mathrm{~mm}^{3}$ were made according to [22]. After 24 hours, those samples were demolded and stored in water up to 28 days.

\subsection{Test Methods}

\subsubsection{Flexural and Compressive Strength Tests}

The compressive and flexural strength of mortars were made as per NF EN 1015-11 [23] using a hydraulic press made by the brand CONTROLS. A test was carried out under constant load of $5 \mathrm{~N} \cdot \mathrm{s}^{-1}$ after 2 days, 7 days and 28 days [24]. Three samples $\left(40 \times 40 \times 160 \mathrm{~mm}^{3}\right)$ of each composition were submitted under flexural tests and sample pieces of the same kind were tested under compression test. So, in all six sample pieces of each composition were made. The compressive and flexural strength values were the average values obtained for these samples. Tests were carried out and the compressive strength values obtained were used to calculate the compression index $\left(I_{R c}\right)$ according to the formula:

$$
I_{R c}=R_{d d} / R_{d o}
$$


with $R_{d \alpha}=$ compressive strength on $d=$ days containing $\alpha=\%$ of glass powder; $R_{d 0}$ compressive strength on $d$ days containing $0 \%$ glass powder.

\subsubsection{SEM Observations}

The microstructure of mortars was investigated using SEM. The SEM was operated by under vacuum and an accelerated voltage of $15 \mathrm{kV}$. A working distance of $3 \mathrm{~mm}$ was applied and a tilt was set to $0^{\circ} \mathrm{C}$.

In order to detect the existence of gel (cement hydrates) and highlight the influence of glass powder on this gel, mortars analysis using Energy Dispersive $\mathrm{X}$-ray Spectroscopy (EDS) was associated to SEM. These tests were performed on mortars (with and/or without glass powder) at 28 and 180 days of age.

\subsubsection{Mortar Bar Test}

To evaluate the effect of glass powder about its ability to limit ASR, mortar bar tests were performed using glass powder as sand partial surrogate. In these test methods, 24 hours after casting, mortar bars were demolded and soaked in water for 28 days. Mortar bars were then transferred into a container with $5 \% \mathrm{HCl}$ solution. Changes in mortar bars' weights were recorded at various points of time. The first reading was done right before soaking mortar bars in the $5 \% \mathrm{HCl}$ solution. Next measurements were made at periodic intervals after soaking in the 5\% $\mathrm{HCl}$ solution up to 50 days. Mortar bars with $0 \% ; 10 \%$; $35 \%$ and $50 \%$ glass powder were used in this study. Mass loss was calculated to assess the trend in mortar bars resistance to the attack from the $\mathrm{HCl}$ solution. Mass loss was expressed by the following equation.

$$
\Delta m=100\left(M_{0}-M_{\mathrm{t}}\right) / M_{0}
$$

with $M_{0}$ the sample mass after 28 days curing in water and $M_{t}$ the sample mass after soaking in the $5 \% \mathrm{HCl}$ solution at different days.

\section{Results}

\subsection{Flexural Strength}

At 2-, 7- and 28-days, the flexural strength of mortars containing both kind of glass powder at different dosages in substitution for sand are shown in Table 3.

At an early age of 2 and 7 days, as the glass powder dosage was increased from $0 \%$ to $50 \%$, the flexural strength increased for both kinds of glass, but from $50 \%$ to $65 \%$ of glass powder, the flexural strength decreased. The same trend is observed in the evolution of the flexural strength for mortars containing both kinds of glass powder at 28 days. However, a comparison of bending strength gains at an early age (of 2 and 7 days) and 28 days shows that bending strength gains for mortars with PBV become greater than those of mortars with PBB at 28 days (Figure 5). PBV and PBB being finer than sand, its partial substitution for both kinds of glass powder of which grain size was spread, can improve the flexural strength of mortars up to a certain substitution rate. On the other hand, change in PBB's bending strength gains at 28 days regarding PBV's bending strength gains depends on glass powders' chemistry. 
Table 3. Flexural strength of different substitution rates in mortars.

\begin{tabular}{ccccccc}
\hline & \multicolumn{5}{c}{ Three point flexural strength (MPa) } \\
$\begin{array}{c}\text { Powder } \\
\text { substitution } \\
(\%)\end{array}$ & \multicolumn{2}{c}{2 days } & \multicolumn{2}{c}{7 days } & 28 days \\
\cline { 2 - 7 } & PBV $(v)$ & PBB $(v)$ & PBV $(v)$ & PBB $(v)$ & PBV $(v)$ & PBB $(v)$ \\
\hline 0 & $1.67(0.36)$ & $1.04(0.26)$ & $2.94(0.54)$ & $2.47(0.42)$ & $3.53(0.87)$ & $4.97(0.68)$ \\
10 & $1.84(0.50)$ & $1.39(0.30)$ & $3.36(0.46)$ & $2.86(0.75)$ & $4.05(0.79)$ & $5.21(0.89)$ \\
20 & $1.95(0.41)$ & $2.64(0.53)$ & $3.62(0.69)$ & $3.36(0.71)$ & $4.24(0.91)$ & $5.30(0.82)$ \\
35 & $2.02(0.55)$ & $2.92(0.44)$ & $3.84(0.67)$ & $3.66(0.80)$ & $4.53(0.83)$ & $5.35(0.87)$ \\
50 & $2.86(0.63)$ & $3.63(0.46)$ & $3.94(0.52)$ & $3.91(0.64)$ & $4.90(0.79)$ & $5.72(0.84)$ \\
65 & $1.85(0.31)$ & $2.91(0.37)$ & $3.57(0.39)$ & $3.62(0.37)$ & $4.17(0.56)$ & $4.23(0.68)$ \\
\hline
\end{tabular}

v: Standard deviation.
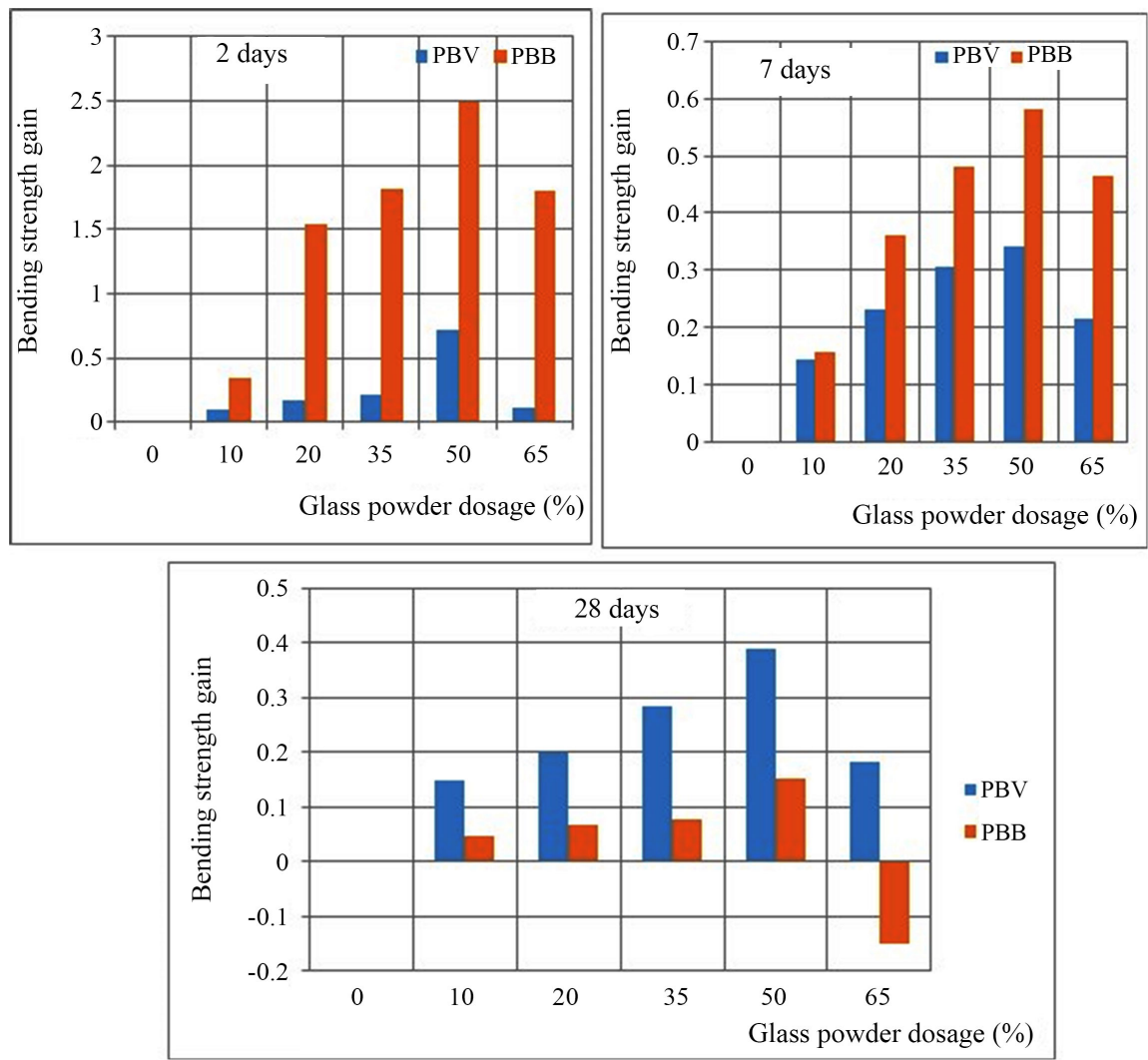

Figure 5. Variation of bending strength gains in function of glass powder dosage at different ages.

This is probably due to the pozzolanic action of the glass powder which develops from medium to long term by increasing the resistance to secondary CSH gel formation and portlandite consumption released by cement hydration [25]. Over 50\% substitution rate, the flexural strength decreases for both mortars. This drop in strength is due to a heterogeneity effect. 


\subsection{Compression Index}

Figure 6 shows the compression index variations of mortars containing different glass powder dosages. As shown in Figure 6, the compression index also increases for both types of glass powder as doses of glass powder in substitution for sand increase by up to $50 \%$. The compression indexes of PBB glass powder are greater than those of PBV glass powder. But at 28 days, the indexes of PBV glass powder become greater. Same notices were obtained for flexural indexes. Therefore, the mortar rupture mode was not responsible for those results, but the presence of glass powder. This suggests that an increase in glass powder dose in substitution for sand can effectively improve the compressive strength of mortars because glass powder is known as an effective pozzolanic material according to [19].

\subsection{Reaction with $\mathrm{HCl}$ Solution}

Weakly concentrated $\mathrm{HCl}$ solution is used to attack samples with the aim at destroying the current portlandite. This is reflected macroscopically by a mass loss of samples. Figure 7 shows mortars' mass loss at different maturation ages. In general, mass loss decreases while glass powder content increases whatever the age of the mortar. In addition, the figure also indicates that for samples containing glass from 2 to 28 days of maturation, the mass loss increases while beyond that period, it decreases with the maturation period except for samples without glass powder. This variation is due to a reaction between glass powder and portlandite that occurs over time. In fact, during this reaction of portland cement with water, tricalcium silicate and dicalcium silicate are transformed into calcium silicate and calcium hydroxide or portlandite $\left(\mathrm{Ca}(\mathrm{OH})_{2}\right)$. Part of the $\mathrm{Ca}(\mathrm{OH})_{2}$ is involved in the hydration of tricalcium aluminate and tetracalcium ferroaluminate. What is left over is in the cured cement in the form of solution or solid. It can generate multiple reactions: ASR and pozzolanic reaction. These reactions are responsible for damage (ASR) or performance improvement (pozzolanic reaction) of the concrete.

\subsection{SEM Observation and EDS Analysis}

SEM observations of samples structure show lots of differences (Figure 8). After 180 days of storage, pictures of samples without substitution indicate that cracks appear in the matrix and on the interfaces of crushed glass matrix (Figure 8(b) and Figure $8(\mathrm{c})$ ). This does not appear on the pictures of same samples observed at 28 days of age (Figure 8(a)). On other pictures of samples containing 35\% glass powder at 28 and 180 days, no crack appears neither in the cementing matrix nor on the interfaces of crushed glass matrix (Figure 8(d) and Figure 8(e)).

An EDS analysis of crushed glass matrix interfaces for samples without glass powder at 180 days indicates the formation of an intermediate compound in these zones. This compound presents a great content in silicone ( $\mathrm{Si}$ ), a small quantity of calcium (Ca) and potassium (K) (Figure 9). This composition is characteristic of the presence of alkali-silica gel [26]. Cracking of the matrix and 
crushed glass separation would result from the formation of this compound (Figure 8(c)).

Difference in samples structure can be explained by the action of glass powder on micro cracking formation. According to (the authors), there is a reaction between glass powder and cement. This reaction supports micro-cracks development and crushed glass separation from of cementitious matrix. The addition of glass powder causes another reaction which contributes to improve the structure by preventing micro cracks and separation of crushed glass-cement interfaces. This reaction inhibits or contributes to close micro-cracks (Figure 8(d) and Figure $8(e))$. That explains the increase in the mechanical performances, the density, the decrease of porosity and the attrition rate.

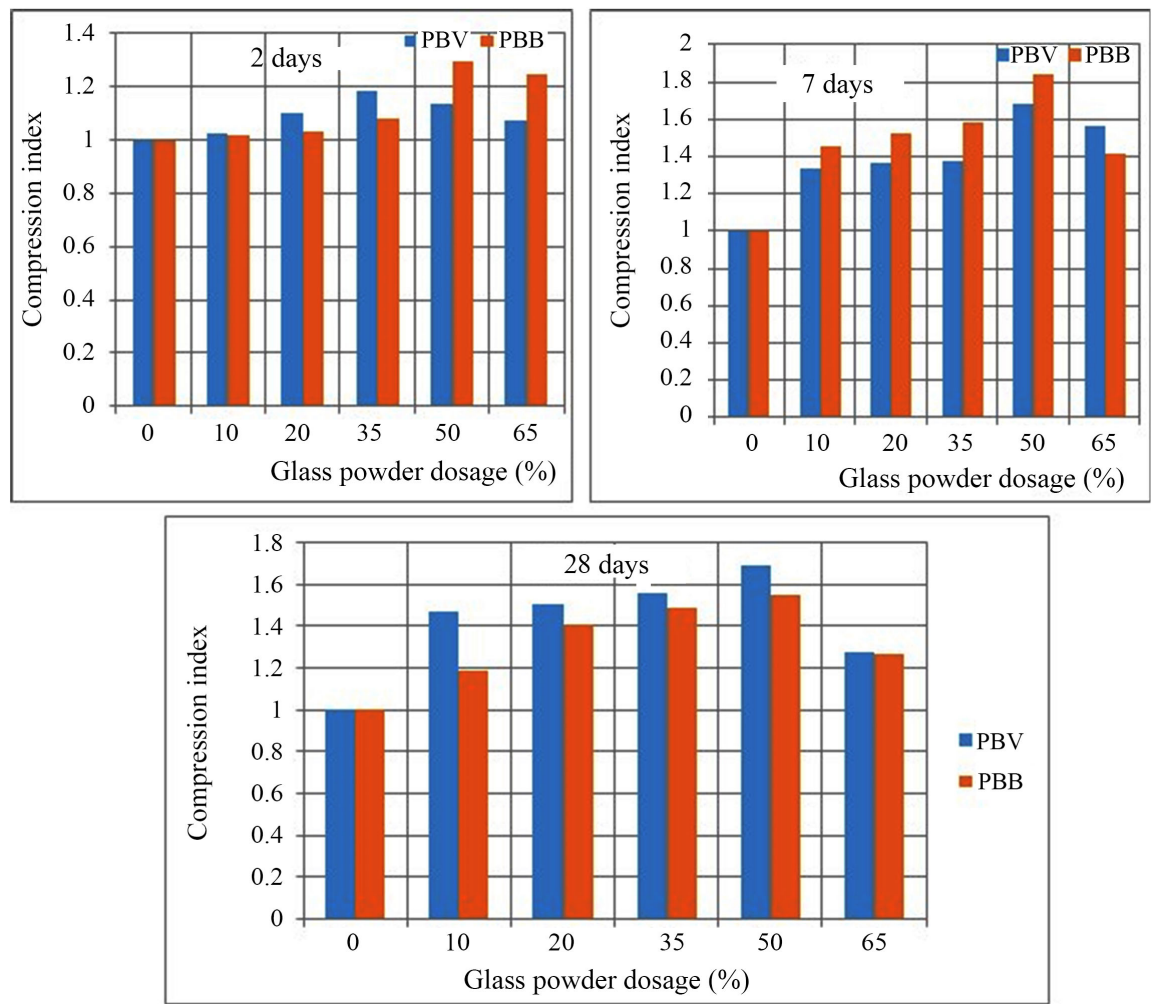

Figure 6. Variation of compression index in function of glass powder dosage at different ages.

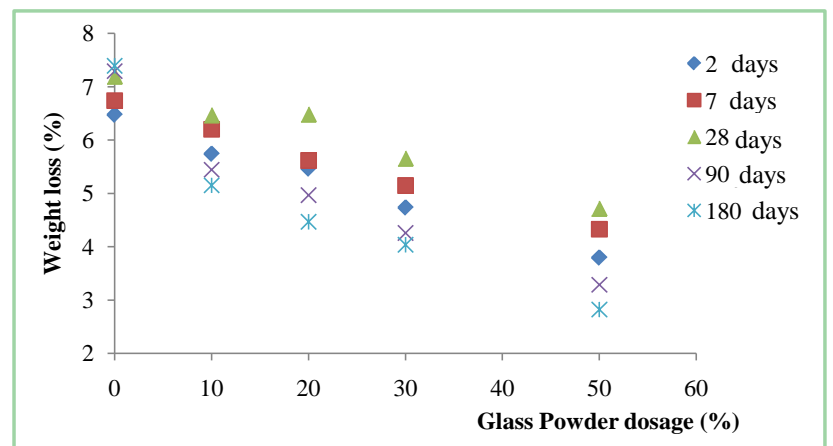

Figure 7. Variation in weight loss of mortars immersed into $\mathrm{HCl}$ solution. 

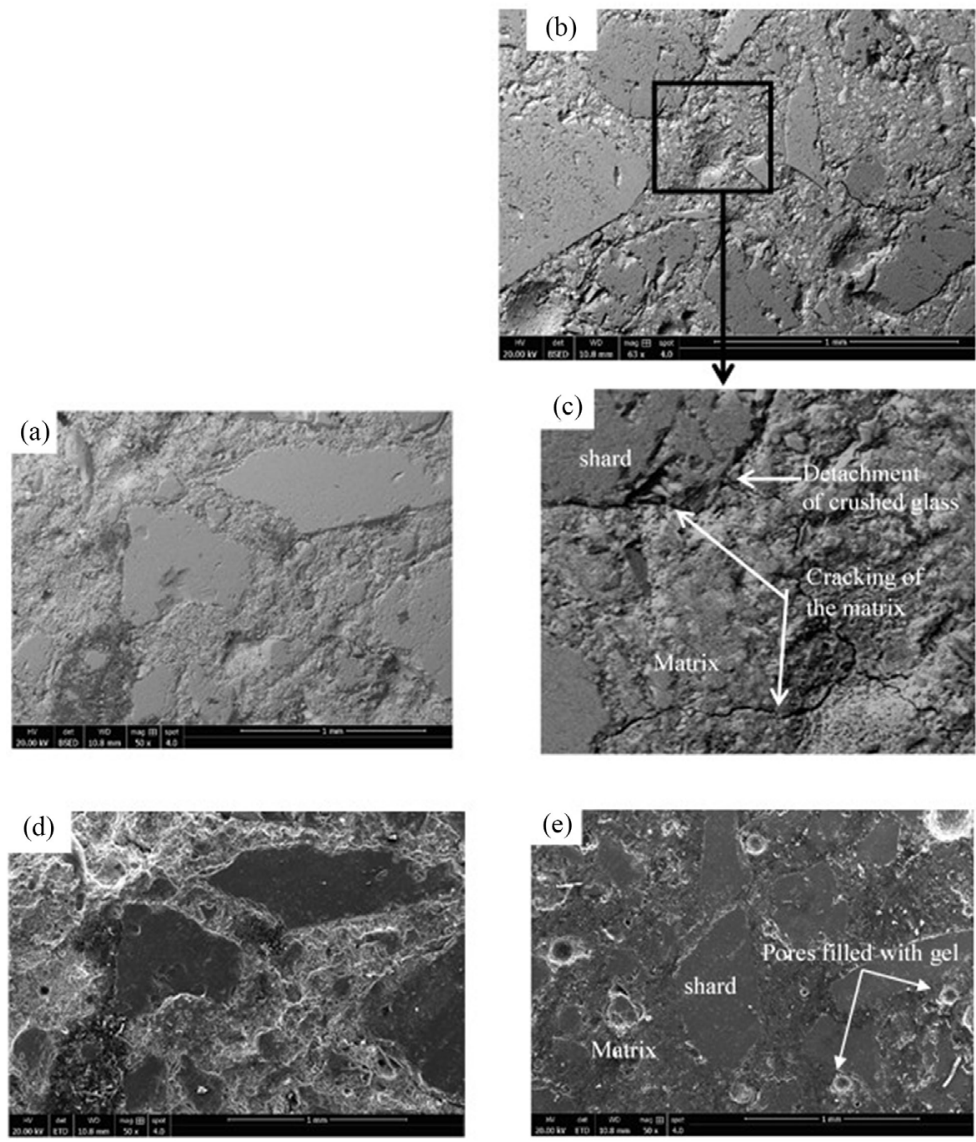

Figure 8. SEM micrographs of mortars containing cement-shard (a) without glass powder at 28 days (b) without glass powder at 180 days (c) zoom in mortar without glass powder at 180 days; (d) with $35 \%$ of glass powder at 28 days; (e) with $35 \%$ of glass powder at 180 days.

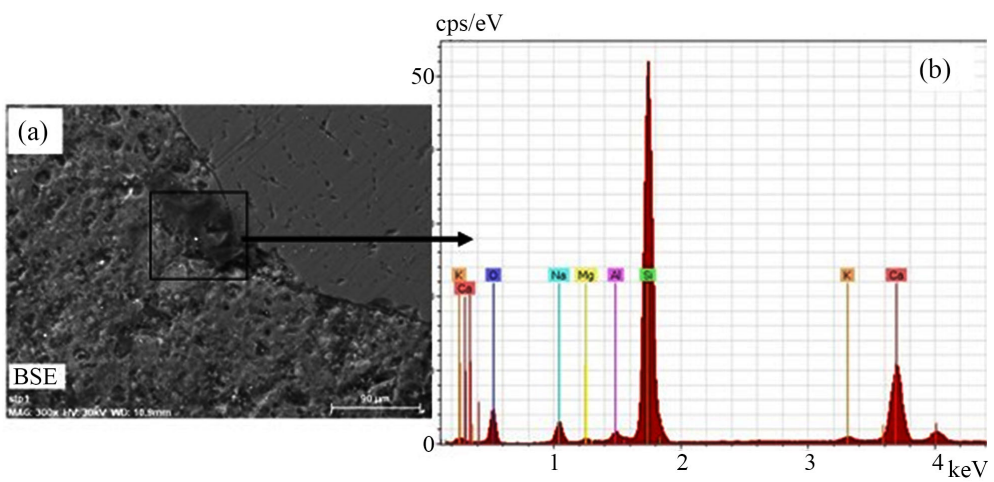

Figure 9. Sample without glass powder at 180 days (a) SEM image (b) EDS plot of zone near shard.

\section{Conclusions}

This study deals with the partial substitution of sand for glass powder in sand cement mortar containing broken glass shards with diameters going from 1 to 5 $\mathrm{mm}$. Different ratios of glass powder were incorporated in mortars and submitted to mechanical tests at 2; 7 and 28 days. The following conclusion can be 
drawn from results analysis:

- The presence of broken glass shards in mortars resulted in micro-cracks formation and matrix detachment although its resistance still increases until 28 days of age. Cement crystallization and alkaline silica reaction were responsible for this phenomenon.

- The addition of glass powder (diameter $<1 \mathrm{~mm}$ ) improves the flexural and compressive strength of mortars because of additional CSH formation into pores. These CSH came from a reaction between the calcium hydroxide released during cement hydration and silicate gel from glass powder.

- The strength increase at 28 days is superior to $20 \%$ and $4 \%$ strength for mortars without glass powder respectively in compression and flexion when the glass powder is superior or equal to $10 \%$. It can be understood that if the mortars' strength increases less when glass powder increases, an optimum glass powder content is reached at about $20 \%$.

This study shows that crushed glass and glass powder can be used as aggregates in construction.

The addition of glass powder improves mortars' mechanical properties (flexural and compressive strengths) over a long-term by forming secondary CSH which fills into pores and improves particles adhesion to cementitious matrix and mortars' resistance to acid solution.

\section{Conflicts of Interest}

The authors declare no conflicts of interest regarding the publication of this paper.

\section{References}

[1] Rashed, A.M. (2014) Recycled Waste Glass as Fine Aggregate Replacement in Cementitious Materials Based on Portland Cement. Construction and Building Materials, 72, 340-357. https://doi.org/10.1016/j.conbuildmat.2014.08.092

[2] Lemontri 2019 le recyclage du verre. https://lemontri.fr/le-recyclage-du-verre

[3] Verre avenir (2019) Le recyclage du verre. http://www.verre-avenir.fr/Le-recyclage-du-verre/L-histoire-du-recyclage

[4] Le journal de Québèc (2019) Une solution trouvée pour recycler toutes les bouteilles en verre.

https://www.journaldequebec.com/2019/08/12/une-solution-trouvee-pour-regler-la -crise-du-verre

[5] OMS (2018) Paludisme. Le rapport de cette année en un clin d'œil. https://www.who.int/malaria/media/world-malaria-report-2018/fr

[6] Djomo, S.A., Kouakou, C.H., Kouadio, K.C., Boffoué, M.O. and Emeruwa, E. (2016) Détermination d'une formulation de carreaux monocouche avec une incorporation de tessons de bouteille de verre. International Journal of Innovation and Applied Studies, 17, 269-274.

[7] Larive, C. (1998) Combined Contribution of Experimentation and Modeling to the Understanding of the Alkali Reaction and Its Mechanical Effects. OA 28, Central Laboratory Presses of Roads and Bridges, $278 \mathrm{p}$. 
[8] Dehaudt, S. (2002) Study of the Degradation of Concrete Subjected to Alkali-Silica Reaction. Ph.D. of the University of Lille, Lille, 215 p.

[9] Marzouk, H. and Langdon, S. (2003) The Effect of Alkali-Aggregate Reactivity on the Mechanical Properties of High and Normal Strength Concrete. Cement and Concrete Composites, 25, 549-556. https://doi.org/10.1016/S0958-9465(02)00094-X

[10] Constantiner, D. and Diamond, S. (2003) Alkali Release from Feldsars into Pore Solution. Cement and Concrete Research, 33, 549-554. https://doi.org/10.1016/S0008-8846(02)01001-3

[11] Gillott, J.E. and Rogers, C.A. (2003) The Behaviour of Silico Car Bonite Aggregats from the Montreal Area. Cement and Concrete Research, 33, 471-480. https://doi.org/10.1016/S0008-8846(02)00956-0

[12] Longuet, P., Burglen, L. and Zelwer, A. (1974) The Liquid Phase of the Hydrated Cement. Building Materials and Public Works Review, 676, 35-41.

[13] Byars, E.A., Zhu, H. and Morales, B. (2004) Conglasscrete I, Final Report to the Waste and Resources Actions Programme. University of Sheffield, Sheffield.

[14] Pereira de Oliveira, L.A., Castro Gomes, G.J.P. and Santos, P. (2008) Optimization of Pozzolanic Reaction of Ground Waste Glass Incorporated in Cement Mortars. University of Beira Interior, Covilha.

[15] Idir, R., Cyr, M. and Tagnit-hamou, A. (2010) Peut-on valoriser massivement le verre dans les bétons? Etude des propriétés des bétons de verre. Technologie Valorisation, 16, 70-77.

[16] Locher, F.W., Richartz, W. and Sprung, S. (1976) Erstarren von Zement 1, Reaktion und Gefùgeentwicklung. Zement-Kalk-Gips, 29, 442.

[17] URDA-NRC (2002) Field Book for Describing and Sampling Soils, Version 2 Comparaison d'échelle et classifications granulométriques. 2.

[18] ASTM C150 (2004) Standard Specification for Heat-Treated Flat Glass-Kind HS, Kind FT Coated and Uncoated Glass.

[19] ASTM C618 (2015) Specification for Coal Fly Ash and Raw or Calcined Natural Pozzolan for Use in Concrete. ASTM International, West Conshohocken.

[20] Islam Sadiqul, G.M., Rahman, M.H. and Kazi, N. (2017) Waste Glass Powder as Partial Replacement of Cement for Sustainable Concrete Practice. Internationnal Journal of Sustainble Built Environment, 6, 37-44. https://doi.org/10.1016/j.ijsbe.2016.10.005

[21] NF P 15-403 (1996) Sable normal et mortier normal. AFNOR, Paris.

[22] NF EN 196-1 (2005) Methods of Testing Cement. Determination of Strength. European Committee for Standardization, Brussels.

[23] NF EN 1015-11 (2000) Méthode d'essai des mortiers pour maçonnerie Partie 11: Détermination de la résistance en compression du mortier durci. AFNORM, Paris.

[24] Benkaddour, B., Fatiha, K. and Abdelaziz, S. (2009) Durability of Mortars Natural Pozzolan and Artificial Pozzolan. Nature and Technology, 1, 63-73.

[25] Ghrici, M., Said-Mansour, M. and Kenai, S. (2005) Effet de la combinaison de la pouzzolane et du calcaire sur les propriétés des mortiers et des bétons. CIRCDD, Alger 3-4.

[26] Moisson (2005) Contribution à la maitrise de la réaction Alcali-Silice par ajout de fines de granulats réactifs dans le béton. Thèse de l'Institut National des sciences appliquées de Toulouse, 203 p. 